\begin{tabular}{|c|c|c|c|}
\hline KULTURA & \multicolumn{2}{|c|}{$\begin{array}{l}\text { POLSKA AKADEMIA NAUK } \\
\text { KOMITET SOCJOLOGII } \\
\text { INSTYTUT STUDIÓW POLITYCZNYCH }\end{array}$} & ISSN 0023-5172 \\
\hline$S$ & 2010, nr 2 & KULTURA - MEDIA - JĘZYK & \\
\hline
\end{tabular}

MAGDALENA HASIUK

Łódź

\title{
QUASI-BIBLIJNA HISTORIA
}

\section{ŹRÓDŁA}

Ariane Mnouchkine, podobnie jak wielu twórców teatru europejskiego przed nią — dramaturgów, reżyserów i teoretyków, swoją wizję sztuki scenicznej stworzyła $\mathrm{w}$ dialogu $\mathrm{z}$ teatralnymi tradycjami Orientu. Jej młodzieńcza, trwająca niemal półtora roku, podróż po Kambodży, Indiach, Japonii i Chinach zrealizowana na początku lat sześćdziesiątych XX wieku okazała się fundamentalna, nie tylko dla powstania Théâtre du Soleil (1964), ale także dla specyfiki podejmowanej tam pracy. Typowo francuska wizja teatru popularnego, reagującego na problemy współczesnego świata w realizacjach tego zespołu spotyka się bowiem $z$ fascynacją pięknem i bogactwem wschodnich form, a w sposób szczególny z rzemieślniczym rygorem orientalnych aktorów. Przedstawienia tworzone w ciągu 46 lat w Théâtre du Soleil sytuują się niejako na przecięciu dwóch wielkich grup tradycji: zachodniej dramaturgii i teatru społecznie zaangażowanego oraz sztuki aktorskiej inspirowanej tradycyjnymi teatrami Wschodu. Należy dodać, że Orient powraca w spektaklach Mnouchkine nie tylko jako rezerwuar inspiracji formalnych, ale także jako źródło tematów, szczególnie istotne od czasu nawiązania przez zespół współpracy z pisarką Hélène Cixous (początek lat osiemdziesiątych). Dramaty Cixous poprzez przybliżenie problemów społeczeństw nieuropejskich (ludobójstwa w Kambodży, podziału Indii, powodzi w Chinach powodowanych przez gospodarkę człowieka) z jednej strony pobudzają świadomość obywatelską widzów Cartoucherie („Kambodża to także nasza historia"), z drugiej strony zwracają uwagę na wymiar mitu obecnego we współczesnych tematach. Podział Indii jawi się w takiej perspektywie nie tylko jako opowieść o sytuacji polityczno-społecznej odległego kraju,

Adres do korespondencji: mahas@go2.pl 
ale także jako metafora separacji doświadczanych indywidualnie przez każdego $z$ widzów. Indiada albo Indie $z$ ich snów, spektakl o podziale, ukazując działanie sił, które go pogłębiają, ale i tych, które przed nim chronią, może sprawić, że publiczność z większą zadumą zajmie stanowisko wobec rzeczywistych rozłamów, uświadomi sobie, jak ważne są nie tylko indywidualne sny o świecie, ale także poszerzanie własnej świadomości, obywatelskiej i ludzkiej.

\section{PODZIAŁ INDII — O MIŁOŚCI ZAKOŃCZONEJ PORAŻKĄ}

Podczas pracy nad sztuką o Kambodży Straszna, ale niedokończona historia... (1985) pojawił się pomysł spektaklu poświęconego Indiom ${ }^{1}$. Théâtre du Soleil, wykorzystując orientalną historię, zamierzał opowiedzieć o uniwersalnych problemach ${ }^{2}$. Hélène Cixous miała przygotować tekst. Chciała napisać dramat na temat Indiry Gandhi. Prawie przez rok czytała książki i artykuły pisane przez Hindusów, Pakistańczyków i Anglików, zapoznała się z dokumentami, studiowała poezję. Uczyła się historii i geografii Indii. Na pewnym etapie pracy zdała sobie jednak sprawę, że aby mówić o Indirze Gandhi musi cofnąć się do Gandhiego i Nehru oraz do wydarzeń kluczowych dla współczesnej historii subkontynentu. Zdecydowała, że w nowym dramacie opowie o odzyskaniu niepodległości przez Indie $\mathrm{w} 1947 \mathrm{r}^{3}$ Postanowiła napisać o dniu radości, który stał się dniem żałoby (Cixous 1987b, s. 11) ${ }^{4}$.

Czterysta milionów Hindusów różnych religii i kast — połączonych zrozumiałym dla wszystkich pragnieniem odzyskania niepodległości - przez czterdzieści lat wspólnie podążało „w kierunku swojej Ziemi Obiecanej”. „I ten szlachetny marsz nagle zmienił się pod wpływem przeciwpragnienia. Idąc ku niepodległości, czemuś, co miało oznaczać narodziny, [...] święto, [Hindusi M.H.] podążali ku tragedii. Świadomość, że w drodze naprzód idziemy [jed-

1 Anne Neuschäfer pisała o dyptyku, jaki tworzyły oba przedstawienia (www.lebacausoleil. com).

2 Patrice Pavis (1990, s. 204) wymiar ideologiczny przedstawienia Cixous/Mnouchkine określił jako humanizm naiwny i uniwersalny.

3 Temat spektaklu traktującego o podziale Indii był dla teatru nowy. Istniała natomiast książka Salmana Rushdiego Dzieci Pótnocy (Midnight's Children) z 1981 r. Ostatecznie premiera Indiady odbyła się 30 września $1987 \mathrm{r}$.

${ }^{4}$ Praca nad tekstem Indiady przebiegała podobnie jak w przypadku Strasznej, ale niedokończonej historii... - Cixous prezentowała gotowe fragmenty aktorom. W razie konieczności dostosowywała je, skracała i zmieniała. Zmiany wiązały się z kondensacją wypowiedzi i całych scen oraz ze znikaniem niektórych postaci. Jako przykład mogą posłużyć kolejne wersje sceny w więzieniu (1 scena II aktu), z których dopiero czwarta została wykorzystana w przedstawieniu. Trzy pozostałe zostały opublikowane $\mathrm{w}$ suplemencie do tekstu dramatu. Umożliwiają one prześledzenie przemian pewnych wątków, stopniowej eliminacji postaci Harilala, a następnie także Kasturbaï. W ostatecznej wersji kluczowym dla tej sekwencji był monolog Gandhiego. W dodatku do tekstu dramatu można było także odnaleźć dwie wersje sceny finałowej, z których bardziej skondensowana pojawiła się w przedstawieniu. Celem wszelkich zmian tekstu było uczynienie go jak najbardziej przejrzystym, „nagim”, w takim stopniu, w jakim to możliwe. 
nocześnie - M.H.] w kierunku szczytu i otchłani, sama w sobie jest godna opowieści" 5 - podkreślała dramaturg $\mathrm{w}$ jednym $\mathrm{z}$ wywiadów (wypowiedź Hélène Cixous w: Golfier 1988, s. 82). Nadzieja na niepodległość przerodziła się w wojnę domową zakończoną podziałem na Indie i Pakistan. Subkontynent odzyskał wolność za cenę rozdarcia. Mapa Indii zawieszona w holu wejściowym Cartoucherie - przypominająca wielkie serce - ukazywała to „pęknięcie”. Podział Indii, kraju oznaczającego dla Mnouchkine i Cixous wewnętrzne królestwo każdego człowieka, symbolizował separacje dotykające rodzin i relacji partnerskich, doświadczane bez względu na epokę i kulturę. Pisząc o spektaklu Patrice Pavis (1990, s. 205) podkreślał: „Kronika polityczna staje się parabolą na temat ludzkiego serca podzielonego i rozdartego. Indie są pretekstem, okazją, aby mówić o mnogości, cierpieniu, rozdarciu ludzkiej duszy. Tekst Cixous powtarza uniwersalne konkluzje". O dążeniu do uniwersalności w dramatach autorki La Pupille, przygotowanych dla Théâtre du Soleil, wspominał także Jean-Marie Thomasseau (1995, s. 169). Obrazy „rozerwanego ciała”, „matki z rozprutym brzuchem”, „Indii pociętych jak mięso”, „ocalenia, które będzie [...] kosztować duży kawał ciała", przywoływane w spektaklu przez Gandhiego i Nehru, stanowiły także metaforę wewnętrznego rozbicia doświadczanego przez niemal każdą ludzką istotę. W kluczowej dla dramatu scenie podziału (2 scena IV aktu) Pandit Jawaharlal Nehru mówił:

Nehru: — „To nie wina Jinnaha. To nasza wina. To tajemnicza ludzka słabość. Nie kochamy wystarczająco siebie nawzajem. I ja sam siebie dzielę tak często. Moja dusza jest polem walki, skąd myśl wynurza się jedynie za cenę masakry pragnień" (Cixous 1987a, s. 164).

Historia Indii zaprezentowana na scenie Cartoucherie stała się metaforą dziejów miłości zakończonych porażką. Dla wielu francuskich widzów Indiada... stanowiła pretekst do refleksji na temat rozwodów (por. Temkine 1987, s. 10). W jednym z komentarzy Cixous zastrzegła, że dla kogoś takiego jak Gandhi, kto miłość traktuje jako nadrzędną wartość, klęska w miłości nigdy nie jest ostateczna. Zawsze pozostaje wiara, że separacja może być naprawiona i po kilku latach ponownie uda się połączyć to, co rozdzielone (wypowiedź w: Golfier 1988, s. 82). W innym komentarzu dramaturg precyzowała: „Historia, która nosi nazwę fatalnego Podziału, jest naprawdę historią ogromnej miłości. Miłość, o nią chodzi poza polityką i religią [...]. Czy można mówić o miłości dziś w sferach publicznych, w polityce? Jaki szef państwa może sobie pozwolić na pytanie: czy kochamy siebie nawzajem? [...]. Hindusi mówili o miłości przez 30 lat, to prezent, jaki Indie przez Gandhiego złożyły światu” (Cixous 1987b, s. 13-14). Micheline Servine (1988, s. 167) określiła dzieło Théâtre du

\footnotetext{
5 Françoise Quillet (1999, s. 200, 204) pisząc o Indiadzie albo Indiach z ich snów zwróciła uwagę na współistnienie $\mathrm{w}$ dramacie na poziomie fabuły dwóch aspektów czytelnych $\mathrm{w}$ przedstawieniu: burzenia i tworzenia, oraz na ich związek z triadą kreacja-utrzymanie-destrukcja reprezentowaną przez trójcę Brahma-Wisznu-Sziwa.
} 
Soleil jako „celebrację miłości”. Zdarzało się, że krytyka dotyczyła płaczliwości dyskursu i sentymentalności polityki dominujących w przedstawieniu (Pavis 1990, s. 217).

„Aby robić teatr, trzeba odnaleźć ukryty mit. To on nadaje sytuacji ludzkiej wymiar poetycki" - pisała Cixous (1989, s. 74). On także pozwala widzom, bez względu na ich kulturę i „obywatelskie” zainteresowanie (bądź ich brak) losem odległego kraju, odnaleźć się w centrum opowiadanej na scenie historii (Coen 1987, s. 37). W Indiadzie w bardziej czytelny sposób niż w kambodżańskim fresku pojawiły się uniwersalne figury losu ludzkiego. Dostrzec można było podobieństwo do wątków występujących w Biblii, Mahabharacie i w tragediach greckich ${ }^{6}$. Powracał temat bratobójstwa - najgorszej z wojen, w której rozrywa się tkaninę, z której utworzona jest rodzina (por. wypowiedź Cixous w: Golfier 1988, s. 82).

Haridasi, wędrująca Bengalka, komentowała pierwszy w dramacie konflikt między Indyjskim Kongresem Narodowym i Ligą Muzułmańską.

Haridasi: — „Dwaj synowie, jedna matka/Jeden bardziej butny niż drugi/To wojna" (Cixous 1987a, s. 37).

Charakterystyka sytuacji wyrażona $\mathrm{w}$ formie sentencji zawiera esencję całej Indiady.

\section{SPEKTAKL-MATKA}

Reżyserka Ariane Mnouchkine nazywała Indiade „przedstawieniem matrycowym, spektaklem-matką" (wypowiedź w: Costaz 1987, s. 18). Istotnie, stało się ono poniekąd matrycą, z której narodziły się kolejne - Atrydzi, a także I nagle noce przebudzenia... oraz Ostatni karawanseraj. Jednakże pominięcie przez reżyserkę odwołań do tradycji elżbietańskiej nie wydaje się do końca słuszne. Choć w mniejszym stopniu niż spektakl o Kambodży, Indiada także wyrastała $z$ inspiracji pisarstwem Szekspira, które Cixous połączyła z „indyjską” specyfiką i odrębnością. Ślady „indyjskości” widoczne były już w samym tytule: Indiada albo Indie $z$ ich snów. Pierwszy jego człon odsyłał do Iliady. Drugi, szczególnie ważny dla pisarki, przywoływał indyjską mnogość, mozaikę złożoną z wizji Mahatmy Gandhiego, Pandita Jawaharlala Nehru, Mohameda Ali Jinnaha, ale także $z$ rozlicznych wizerunków kraju o stu obliczach, różnych językach i religiach. $Z$ różnorodności Indii wynikał jeden z podstawowych celów stawianych przez Théâtre du Soleil. Polegał on na znalezieniu odpowiedniej sceny i formy dla zaistnienia tak wielu różnorodnych elementów. Na każdym etapie pracy nad tekstem i spektaklem autorka oraz zespół stawali wobec zagadki — w jaki

\footnotetext{
${ }^{6}$ Françoise Quillet (1999, s. 178-179) pisała: „W Indiadzie Indie porównane zostały do żywego ciała, które Jinnah chce pociąć. Decyzja Jinnaha przypominała czyn Agamemnona poświęcającego Ifigenię, decyzję Bolingbroke’a o zabiciu Ryszarda II i w Wiarotomnym mieście wybór lekarzy, którzy zgodzili się na sprzedaż zakażonej krwi".
} 
sposób ukazać jedność i sprzeczność podzielonego narodu (por. wypowiedź Cixous w: Gastellier 1987). Temat marzenia, obok miłości, był jednym z kluczowych w dramacie. Powtarzał się w wypowiedziach wielu postaci - Gandhiego, Mountbattena, Sarojini. Jednocześnie podtytuł tekstu nawiązywał do książki Mahatmy Gandhiego India of My Dreams (Gandhi 1962). Quillet dodatkowo widziała w podtytule Indiady nawiązanie do tematu utopii ${ }^{7}$, czytelnego we wcześniejszych przedstawieniach Théâtre du Soleil, w sposób szczególny w Roku 1789.

Bezpośrednich odwołań do osoby i dzieł Szekspira ${ }^{8}$ w Indiadzie niemal zupełnie zabrakło, ale formą nawiązywała ona do kronik szekspirowskich. Podstawowym źródłem odwołań i cytatów natomiast była Biblia z kluczowym obrazem sądu salomonowego ${ }^{9} \mathrm{w}$ kulminacyjnej 2 scenie IV aktu. Autorka La Pupille z mniejszą swobodą zmieniała miejsca akcji, ograniczając je do subkontynetu. Połowa z osiemnastu scen rozgrywała się w New Delhi, cztery w Bombaju. Dramat, podzielony na pięć aktów, uporządkowany według schematu tradycyjnej dramaturgii, składał się z ,jednej epoki”. Obejmował także krótszy czas niż fresk kambodżański — od roku 1937 do 1948. Patrice Pavis (1990, s. 216, 223) zarzucał Cixous „zuchwałe spojrzenie na historię”, a o spektaklu pisał: „Za czytelność wydarzeń, etnologiczną, geopolityczną Indiada zapłaciła całkowitym uproszczeniem historii i nieczytelnością mechanizmów i sprzeczności społeczno-ekonomicznych, które przenikają społeczeństwo indyjskie". Uproszczona wizja dziejów w przedstawieniu poświęconym Indiom była faktem, ale także koniecznością. Wynikała $\mathrm{z}$ pragnienia opowiedzenia $\mathrm{w}$ ciągu pięciu godzin nieznanej i niezwykle złożonej historii. Twórcy Théâtre du Soleil musieli ją skondensować, dokonać wyboru, a o uproszczenia wówczas nietrudno. Obecnie w rozważaniach na temat historii jako nauki podkreśla się, że granic możliwości poznania historycznego nie wyznacza już wiedza, lecz wyobraźnia, a nasza refleksja o przeszłości dostarcza jedynie jej kolejnych wizji, różnych interpretacji. Czy tym bardziej artyści nie mają prawa do własnego odczytania dziejów? Nawet jeśli byłaby to wizja historii, w której sprzeczności społeczno-ekonomiczne doświadczane przez określone społeczeństwo potraktowane zostałyby marginalnie. Warto zaznaczyć, że pewne wzmianki o problemach ekonomiczno-społecznych — biedzie, rozwarstwieniu, niesprawiedliwości wynikającej także z systemu kastowego — obecne były w dialogach prostych ludzi.

\footnotetext{
${ }^{7}$ Na temat utopii w Indiadzie zob. także Servin 1988, s. 171.

8 Jedyne nawiązanie występowało w poetyckim monologu Lorda Mountbattena, który w 1 scenie IV aktu w apostrofie do Nocy mówił: „To w takie noce w sztukach/Szekspira obejmowały się skazane miłości [...]".

${ }_{9}$ Quillet (1999, s. 184) zwracała uwagę, że w przeciwieństwie do niektórych odwołań szekspirowskich w kambodżańskim fresku w Indiadzie nawiązania biblijne były zawsze poważne, nigdy nie ironiczne. Służyły jako metafora sytuacji lub postaci obecnej na scenie.
} 
Przedstawienie nie służyło widzom jako jedyne źródło wiedzy o subkontynencie, ale - jak sugerował Hayden White (2000, s. 24), pisząc o refleksji historycznej - stanowiło pretekst do rozmyślań nad sobą i nad życiem. Ewa Domańska (1994, s. 26) charakteryzując cel pracy nowoczesnego historyka podkreślała: „Odkrywając przeszłość próbuje dotknąć prawdy o świecie. Czasami pisanie o historii wydaje się spełniać wręcz rolę terapii, która ma pomóc autorowi zrozumieć samego siebie. Historia w takim wydaniu staje się z ducha swego egzystencjalna, jakby indywidualnie subiektywnie oswojona. Pod płaszczykiem opowiadań o przeszłości [...] przekazuje bowiem bliskie każdemu człowiekowi treści”. Komentarz ten śmiało można odnieść do indyjskiej inscenizacji Mnouchkine.

Na scenie w Indiadzie pojawiała się nieco mniejsza liczba postaci niż w sztuce na temat Kambodży. Sceny zachowywały porządek chronologiczny i logiczny zdarzeń. Rozgorączkowanie „historii” ustąpiło wobec wizji rzeczywistości uspokojonej i bardziej kontemplacyjnej. Również liczba wydarzeń, zarówno tych bezpośrednio dziejących się na scenie, jak i przywoływanych czy wzmiankowanych, została wyraźnie zredukowana. Choć i tak pozostawała pokaźna. Przedstawienie sprawiało wrażenie bardziej statycznego, także pod względem ruchu postaci. Podczas większości scen aktorzy grający „zwykłych ludzi” siedzieli na marmurowych stopniach, a ci odgrywający polityków odpoczywali na krzesłach, dywanach, opierali się na gigantycznych poduchach i wałkach. Mnouchkine tak charakteryzowała pierwszą grupę: „Małe postaci, ludzie prości istnieją na scenie jakby czekali na autobus. Może przyjechać za pięć minut, za pięć godzin albo jutro" (wypowiedź w: Cixous 1988, b.n.s.).

Chociaż w dramacie wiele sekwencji zostało zestawionych na zasadzie kontrastu, spektakl dzięki otwartym zmianom dekoracji — podczas których aktorzy grający służbę z rozmachem wnosili i znosili ze sceny dywany i poduszki, polerowali marmur - zyskiwał płynność. Przejścia między scenami charakteryzowały się łagodnością. Zmiany dekoracji rytmizowały przedstawienie, określały zmianę miejsc i upływ czasu. Rytm był ożywiony, ale daleki od dynamiki spektaklu o Kambodży. W Indiadzie słowo „galop” padło tylko raz, w wypowiedzi bengalskiej narratorki komentującej konflikty między rikszarzami:

Haridasi: — „Burza nadciąga galopem...” (Cixous 1987a, s. 94).

Choć kilka replik dalej kłótnie ucichły, a Haridasi uspokajała widzów kolejną metaforyczną sentencją:

Haridasi: — „Burza grzmi. Burza przechodzi” (Cixous 1987a, s. 96).

„Nawałnica” powróciła i wybuchła już w kolejnej scenie w postaci rzezi obecnych w poetyckiej wizji Haridasi i rozmowach między muzułmańskimi politykami (scena 1 akt III). Ramę dla masakr przedstawionych w Indiadzie wyznaczały wypowiedzi Indera, rozmówcy Gandhiego, rikszarza z kasty niedotykalnych. Słowa mężczyzny brzmiały jak klątwa tego, co zmarginalizowane 
i tłumione. W 3 scenie II aktu Inder mówił wprost do widzów. Jego życzenie brzmiało złowieszczo i zarazem tajemniczo ${ }^{10}$ :

Inder: — „Chciałbym, żeby wszyscy wszystkich zabili i żeby wszyscy zostali zabici. Dlatego że ten świat jest całkowicie zły. Wszyscy mówią mój. Mój kraj, mój Pendżab, mój Pakistan, mój Bóg, mój brat. Kiedy burza wybuchnie, nie będzie ani mojego, ani twojego, ani brata, ani przyjaciela, ani boga. I dobrze wam tak będzie, wam wszystkim, którzy kroczycie jak ślepi po nas, zapomnianych tej ziemi" (Cixous 1987a, s. 104).

Jacques Derrida pisząc o tajemnicy jako o sprawie marginesu, podkreślał, że znaczenie nigdy nie jest centralne, a zawsze peryferyjne (cyt. za: Rachwał, Sławek 1992, s. 36-37). W ostatniej scenie dramatu słowa rikszarza, wypowiadane $z$ równą siłą co w II akcie, brzmiały odmiennie:

Inder: - „Chciałbym teraz, żeby wszyscy przestali zabijać wszystkich. Ale to niemożliwe, bo ludzie są zbyt głupi/zwierzęcy"11 (Cixous 1987a, s. 202).

Sposób wypowiadania tekstu w Indiadzie charakteryzował się przeźroczystością. Aktorzy, wcielając się w postaci o różnych temperamentach, z odmiennych grup społecznych i zawodowych, etnicznych i religijnych, dostosowali sposób mówienia, rytm i melodię tekstu do poszczególnych bohaterów. Jednocześnie pozostawali skoncentrowani na tekście i jego przesłaniu. Aktor, jak śpiewak legendarnej historii, przede wszystkim służył tekstowi. „Aspekt” aktora, jego rzemiosła, pozostawał niejako na drugim planie, podporządkowany współczesnej epopei.

Masakry, rozgrywające się i wspominane między przytoczonymi sekwencjami Indera, uruchomiły gigantyczną machinę zbrodni, w której na cios odpowiadano ciosem, by „mordować się w nieskończoność”. Fizycznie słaby, drżący, lecz nieustępliwy Gandhi na próżno, jakby się mogło wydawać, nawoływał do pokoju.

W 2 scenie III aktu masakry zapowiadali nienawidzący muzułmanów Bengalczycy, bracia Hatibaï i Rajiv Sen. Choć Nehru w kolejnych sekwencjach ostro rozprawiał się z ministrami, którzy dopuścili do mordowania wyznawców islamu w Biharze - Georges Bigot mocno stojący na nogach, podparty pod boki

10 Jednym ze źrodeł opisu poszczególnych sekwencji spektaklu jest film Bernarda Sobela zrealizowany dla telewizji. Nie stanowi on wiernego zapisu przedstawienia. Mnouchkine zaakceptowała wersję filmową, choć rozczarowały ją duże skróty. $Z$ pięciogodzinnego materiału powstał obraz trwający 3 godziny 15 minut. Sobel wykorzystał 60-70\% tekstu, wiele scen wyciął, inne zostały wyraźnie skrócone lub przemontowane. Bywało, że zmieniono ich kolejność. Skróty objęły repliki wielu postaci. Niektórzy bohaterowie w ogóle nie pojawili się na scenie. Zabrakło na przykład Diny Jinnah. Niektóre repliki zostały zmienione w porównaniu z wersją tekstu opublikowaną przez Théâtre du Soleil, nieliczne dopisano. Wersję filmową Indiady charakteryzuje klarowność. Paradoksalnie przejrzystość i pewna lekkość pozwalają widzom doświadczyć bogactwa i głębi przedstawianej historii. Kopia filmu jest dostępna w bibliotece teatralnej „Gaston Baty”, która mieści się w gmachu Uniwersytetu Paris III Sorbonne Nouvelle.

$11 \mathrm{~W}$ języku francuskim bête oznacza także rzeczownik „zwierzę” oraz przymiotnik „zwierzęcy”. 
w pozycji przypominającej postawę Ryszarda II (postaci, w którą wcielał się w cyklu szekspirowskim) wykrzykiwał swoje oburzenie - ostatecznie jednak jego działanie okazywało się mało skuteczne. Konflikty zażegnane w jednym miejscu wybuchały gdzie indziej ze zdwojoną siłą.

W pierwszej scenie V aktu Nehru wyrażał swoją bezsilność. Jego monolog przypominał wypowiedź Johna Gunthera Deana o zbrodniach popełnionych w Kambodży. Motywy ziemi we krwi, krwawego żniwa, potopu, obrazy ognia podobne do lamentów chóru i wypowiedzi Kasandry w Agamemnonie jakby zapowiadały kolejne spektakle zespołu. Monolog Nehru pozwalał ukazać „matrycowy" charakter Indiady.

Nehru: — „Ogień! Ogień! Wszystko jest spalone, zgrabione, zamordowane! Przemierzyłem dwa Pendżaby. Dwa piekła [...] Ziemia skąpana w dzikiej farbie. Nazwa Pendżab stała się synonimem rzezi.

Nigdy nie widziałem takiego ludzkiego żniwa. Mężczyźni bez członków, dzieci poćwiartowane, nagie kobiety sprzedawane jak bydło. I ja biegający wszędzie [...] ja wszędzie wrzeszczący: «Przestańcie! Przestańcie! Rozkazuję wam, Hindusi, bracia - nie - potwory, głupie bydlęta, mordercy!». Ja krzyczący do potoku «Przestań płynąć!»; krzyczący do ognia «Przestań nas pożerać!»; krzyczący do niebiosów «Potop! Spuście potop i zmyjcie morderstwa w nieubłaganych falach». Ale na nic! Krzyczałem na próżno! [...]" (Cixous 1987a, 1 scena V akt).

Nasilenie mordów nadal postępowało. W 4 scenie V aktu postaci już nie opowiadały o śmierci, nie groziły nią, ale zadawały ją na scenie. Bracia Sen zabijali Ahmada i jego matkę Imę. Ganga Singh sztyletował Strażnika grobu Świętego Sufiego, pokojowo usposobionego człowieka, który uważał: „Jest tylko jeden Bóg. Dla wszystkich. Jeden jedyny", i dlatego sprzeciwiał się podziałowi kraju. A Bahadur, treser niedźwiedzi, zmuszony był zabić swoją ukochaną Moonę Baloo.

Guy Dumur pisał, że chociaż Indiada przypominała lekcję historii, nie tłumaczyła motywów zamordowania Gandhiego, nie wyjaśniała także przyczyn masakr między hindusami i muzułmanami. Według krytyka, zabrakło w przedstawieniu odwołań do dawnych antagonizmów dzielących obydwa wyznania. Mnouchkine i Cixous, czyniąc głównym odpowiedzialnym za podział Indii i związane $z$ tym tragedie Mohameda Ali Jinnaha, postąpiły stronniczo (Cixous 1987b, s. 54). Wynikało to poniekąd z założenia twórczyni przedstawienia. Reżyserka określała poszczególne postaci za pomocą podstawowych opozycji: dobry/zły, sprawujący władzę/poddany, wykorzystujący/wykorzystywany ${ }^{12}$. Charakterystyka bohaterów stanowiła jeden $z$ elementów zbliżających Indiade do opowieści mitycznej. „Świat mitycznej historii — jak pisze Krzysztof Renik (1994, s. 81) — jest bowiem światem, w którym postacie są w pewien sposób statyczne. Bohater jest albo zły, albo dobry, gwałtowny albo łagodny, głupi lub mądry [...] jest królem lub poddanym".

12 Por. A. Neuschäfer (www.lebacausoleil.com). 
W Indiadzie, podobnie jak w Strasznej, ale niedokończonej historii, można wyróżnić akcję główną - na którą tym razem składały się losy liderów politycznych skupionych wokół Indyjskiego Kongresu Narodowego i Ligi Muzułmańskiej, ich dyskusje, spory i decyzje - oraz akcje poboczne prezentujące losy prostych ludzi. O ile sceny $z$ udziałem elity spotykały się z zarzutem schematyzmu i braku teatralności (Le Roux 1987, s. 26) — postaci referowały odrębne stanowiska polityczne ${ }^{13}$, o tyle krytycy podkreślali dynamikę i szekspirowski wymiar sekwencji dotyczących „zwyczajnych bohaterów” 14, co uzyskano dzięki szybkiemu rytmowi dialogów, tworzących czytelne sytuacje zmieniające się jedna po drugiej. W niektórych scenach akcja główna i poboczne przenikały się, interferując ze sobą. Indiada ukazywała, w jaki sposób decyzje wielkich wpływały na codzienność maluczkich, jak debata ideologiczna „przekładała się” na życie; ale także jak jedno szaleństwo ogarniało polityczny Olimp i zwykłych ludzi. Konsekwencję błędnych decyzji elit stanowiła przelana krew obywateli. Haridasi w 2 scenie II aktu zadawała publiczności pytanie retoryczne:

Haridasi: — „Pytam się, czy tak samo jest na górze jak na dole?” (Cixous 1987a, s. 97).

\section{WIELKA POLITYKA I „ZWYCZAJNE” ŻYCIE}

Forma dramatu charakteryzująca się rapsodycznością, podobnie jak w kambodżańskim fresku, zbliżała się do kroniki szekspirowskiej. Pozwoliła ona Cixous na zaprezentowanie akcji na dwóch planach: makro i mikrokosmosu. Obok świata żywych pojawili się na scenie zmarli (Kasturbaï). Żona Gandhiego pełniła podobną funkcję jak król Suramarit - wspierała Mahatmę radą, chroniła go, pomagała, jak za życia. Również po śmierci pozostawała całkowicie podporządkowana Bapu.

Cixous ukształtowała Indiade łącząc różne formy literackie. W przedstawieniu mieszały się elementy historiografii, przemów teologicznych i filozoficznych dyskusji oraz fragmenty poetyckie. Celem połączenia różnorodnych form było ukazanie całkowitości ludzkiej istoty, postrzeganej w różnych planach i aspektach (zob. Picard 1989, s. 21). Poetyckość tekstu oraz dynamika spektaklu rodziły się z połączenia: zbliżenia i dystansu, aspektu indywidual-

13 Z kolei Colette Godard (1987, s. 19) krytycznie pisała o pierwszej części przedstawienia, toczącej się wokół dyskusji na temat podziału. „Mimo piękna poszczególnych obrazów [...] pragnienie informowania zmienia się w dydaktyzm, a i tak nie można odnaleźć się wśród nazwisk trudnych do powtórzenia [...] [Dopiero] druga część przenosi nas w serce dramatu, wojny domowej, wojny świętej. Zwolennicy Gandhiego i Nehru zostali pokonani, zwyciężeni przez dzikość, której nie wyzwolili, której nie mogli ani zrozumieć, ani kontrolować. Żyli z miłości do kraju i narodu i znaleźli się na innej planecie. Naród oczekuje od nich niemożliwego. Przygnębienie, niepewność prowadzą do wściekłości. [Pojawia się] klimat napięcia, oczekiwania, trwogi [...] sylwetki z komiksu osiągnęły wielkość bohaterów tragedii [...]”.

${ }^{14}$ A. Neuschäfer (www.lebacausoleil.com). 
nego i zbiorowego, scen i otwartych zmian scenografii. Podobnie było w poprzednim przedstawieniu. Jednak o ile w Strasznej, ale niedokończonej historii... istniała postać centralna - Sihanouk, który stanowił oś prezentowanej historii, o tyle w Indiadzie Cixous umieściła ponad dziesięć centrów — dziesięć postaci stanowiących „rozproszony układ słoneczny” (Cixous 1987b, s. 16). Niektórzy, jak Gandhi, spotykali się ze wszystkimi postaciami, inni ograniczali się do jednej kasty lub wybranej grupy religijnej. Pojawiły się głosy, że brak postaci centralnej, „organicznie teatralnej, jak Norodom Sihanouk, cudowny klaun, komediant i tragik" (Godard 1987, s. 19), był wadą przedstawienia. Chociaż Raymonde Temkine pisała o trzech głównych bohaterach: Gandhim w interpretacji Andrésa Péreza Arayi, Nehru odgrywanym przez Georgesa Bigota i Jinnahu, w którego wcielił się François Dusigne, to Colette Godard (1987, s. 19) podkreśliła, że nikt z tej trójki nie „przewodzi grze”. Nie czynił tego ani „królewski” Nehru, ani tym bardziej Gandhi — „łagodny staruszek, psotny i dziecinny, trochę marzycielski, lecz pozbawiony dynamizmu". Brak centrum wynikał niejako $z$ samej tematyki spektaklu, $z$ ogromu i różnorodności subkontentu. Istoty bogactwa Indii nie był w stanie ukazać jeden główny bohater, nawet tej miary co Gandhi czy Nehru, rodziła się ona dopiero z połączenia sprzeczności i harmonii odmiennych elementów. Ukazywała ją na scenie grupa liderów, kobiet i mężczyzn różniących się poglądami politycznymi, religijnymi i filozoficznymi, temperamentami, prezentowanymi wartościami.

W porównaniu ze Straszna, ale niedokończona historią... również akcje poboczne w Indiadzie zostały pomnożone. Ogniwem scalającym obydwa poziomy był Mahatma. Warto dodać, że Gandhi, który dla Hindusów „stał się potężnym łącznikiem między ich przeszłością a przyszłością" (Nehru 1957, s. 145), w przedstawieniu łączył świat polityków i ubogich rikszarzy, wieśniaków oraz tresera niedźwiedzi. Jednych i drugich otaczał rodzinną troską ${ }^{15}$. W miejsce historii przyjaźni Khieu Samnol i Pani Lamné w Indiadzie pojawiło się kilka wątków, które przenikały się wzajemnie, łączyły w punktach integracji o szczególnej wymowie (zapowiedź śmierci Kamini, śmierć Ahmada i Imy), a następnie rozdzielały. Losy „zwyczajnych ludzi” pełniły funkcje metafor i metonimii społecznych tragedii. W nich jak pod lupą widzowie mogli dostrzec cierpienie i rozdarcie indyjskiego społeczeństwa. Pełniły one także inną funkcję. Cixous (1987b, s. 16) pisała o Indiadzie jako o sztuce o istocie ludzkiej, „o bohaterze i prochu, o walce zwierzęcia i anioła w każdym z nas”. Temat człowieka/zwierzęcia, bohatera/prochu, choć istniał na poziomie akcji głównej, w akcjach pobocznych został rozwinięty i przedstawiony w kolejnych wariantach, rozpisany na wariacje tematyczne.

\footnotetext{
15 „Gandhi wprowadził w naszą walkę tę surową dyscyplinę i staliśmy się olbrzymią organizacją. Organizacją nie tylko zdyscyplinowaną, lecz także zespoloną więzami mocniejszymi i ściślejszymi, niemal jedną wielką rodziną" - wspominał Jawaharlal Nehru (1957, s. 36).
} 
$\mathrm{Na}$ marginesie warto dodać, że wprowadzone wątki poboczne wymagały od Cixous użycia zupełnie innego języka. O ile dramaturg mogła zapoznać się $z$ wypowiedziami polityków, studiując ich wystąpienia, „nie informacje polityczne, ale zepchnięty dyskurs, prawdziwy tajemniczy [...] język Gandhiego, Nehru i innych" (wypowiedź Cixous w: Hassoun, Maillet, Rabant 1988, s. 67), o tyle miała trudności z określeniem języka „zwyczajnych postaci”. Nieoceniona pod tym względem była druga podróż do Indii i spotkanie $z$ dwiema kobietami-tłumaczkami, od których pisarka otrzymała niezbędną pomoc, jeśli chodzi o język i tradycję. Podczas badań w Europie Cixous nie dysponowała żadnymi dokumentami, notatkami czy listami pozwalającymi „usłyszeć słowa ludu", a podróżując po Indiach nie znała także języków rodzimych mieszkańców i skazana była na tłumaczy. Tak wspominała swoje doświadczenia:

„Podczas pierwszej podróży tłumaczem był mój przyjaciel Hindus, człowiek wykształcony, czarujący, subtelny [...] [który] Nie mógł się powstrzymać, aby nie zająć miejsca innych [...] przede wszystkim kobiety, z którą rozmawiał. Mówił mi: «Ona powiedziała, że» i to, co kobieta powiedziała, podawał na tacy, doprawione w metaforyczny sposób [...]. A ja potrzebowałam nie tyle informacji, ile przede wszystkim znaczącego. Chciałam, żeby ktoś mi podał dokładnie słowo po słowie [...] bicie serca rodzimego języka w jego oryginalnej niezgrabności. To, co usłyszałabym, rozmawiając z kimś na wsi francuskiej [...] coś, co zostaje blisko ziemi, emocji i co jest samą poezją. Nie mogłam tego otrzymać. W końcu dostałam to dzięki dwóm kobietom - jednej, która jest piszącą muzułmanką. Prosiłam ją o przekład, rybkę, tego, co było mówione na przykład w urdu, nawet jeśli przekład wydawałby się barbarzyński lub barokowy [...]. Następnie moją pośredniczką była Bengalka, poliglotka, młoda kobieta, z którą podróżowałam po wsiach w Bengalu i która wykonała pracę równie przezroczystą. W ten sposób zaczęłam słyszeć, $\mathrm{w}$ jaki sposób boi się bengalski wieśniak. Jego strach nie ma nic wspólnego z naszym strachem; przekazują go inne omamy, inne poruszenia ciała; mówię o «strachu», mogłabym powiedzieć o emocjach, wszystkie emocje przenikają inne obszary niż u nas. Bez tego przekazu nie mogłabym nic zrobić, byłam przed drzwiami. Weszłam w Indie wewnętrzne i muzyczne przez transmówiące [transparlant] ciało kobiet [...]" (wypowiedź Cixous w: Hassoun, Maillet, Rabant 1988, s. 67-69).

Język codziennych emocji usłyszany na subkontynecie Cixous wykorzystała tworząc wątki poboczne: historię bliźniaczych rikszarzy, Rahmana i Ahmada. Ich podobieństwo zostało wydobyte $\mathrm{w}$ przedstawieniu nie tylko przez kostium (identyczny dla wszystkich rikszarzy) i makijaż, ale także postawę ciała i gestykę. W momencie podziału kraju bracia rozdzielili się. Rahman wyruszył do Pakistanu. Ahmad pozostał z matką Imą, która nie chciała opuścić New Delhi, gdzie mieszkała od dziecka. Za tę decyzję i ona, i syn zapłacili życiem. Scena pożegnania braci (1 scena IV aktu) była poruszająca, gdy Ahmad, „przeglądając się" w swoim bracie jak w zwierciadle, mówił:

Ahmad: — „Bez ciebie Rahmanie będę jak dziecko bez ojca. Ale przynajmniej jeden syn musi zostać z matką. Ja nim będę. O mój Rahmanie, kiedy przybędziesz 
do Pakistanu, tam, pierwszy posiłek, jaki spożyjesz, moja dusza spożyje z tobą. A kiedy staniesz się bogaty i spotka cię pomyślność, uczyń nam ten zaszczyt i przyjedź do Delhi zobaczyć swego brata Ahmada, który zawsze myśli o tobie" (Cixous 1987a, s. 156).

Zabójcami Ahmada i Imy byli Hindusi - bracia Sen, którzy od 2 sceny III aktu regularnie, co jakiś czas przebiegali chyłkiem przez scenę jak dwa złowrogie cienie. Te uosobienia zemsty i żądzy sprowadzały na inne postaci zagładę. W rolę Hatibaïa wcielił się Simon Abkarian, grający również postać Abdula Ghaffar Khana - postawnego patańskiego górala, zwanego „Gandhim granic”, który w imię wyrzeczenia się przemocy zdołał rozbroić srogich i wojowniczych nadgranicznych muzułmanów. Praktyka polegająca na tym, że jeden aktor grał skrajnie różniące się postaci, była typowa dla całego przedstawienia: Jean-François Dusigne wystąpił jako Jinnah oraz Rajkumar, Catherine Schaub odgrywała bratanicę Gandhiego Manu, siostrę Jinnaha Fatimę i niedźwiedzicę Moonę Baloo, Asil Rais (jeden z dwójki Hindusów w zespole) wystąpił jako poeta Mohamed A. Iqbal, Lord Mountbatten, Wysłannik i zabójca Gandhiego Nathuram Godse ${ }^{16}$. Aktorzy odgrywający skontrastowane postaci w odmienny sposób wykorzystywali ciało, głos, sposób poruszania, kształtowali wewnętrzny rytm bohaterów, w inny sposób zajmowali przestrzeń. Zawsze była ona zakomponowana w sposób plastyczny, $\mathrm{z}$ troską o równowagę obrazu. Uwagę zwracała klarowność, czytelność i precyzja gestów wykonawców, bez "gestycznego gadulstwa”. Rzadziej aktorzy poszukiwali tonu „uniwersalnego”, podkreślając podobieństwo różnych bohaterów. Mountbattena, Iqbala, Godse różniły poglądy, motywacje czynów i same działania, ale postawa ciała Raisa, jego sposób mówienia, a nawet ton głosu w każdej z przywołanych ról były podobnie elektryzujące. Wypowiadane słowa dochodziły do widzów jakby zza jakiejś niewidzialnej kurtyny, zaświatów. Nieco inaczej wykonawca interpretował rolę Wysłannika. Pisząc o aktorstwie Dusigne'a, Cixous (1988, b.n.s.) zwróciła uwagę na jeszcze jeden aspekt obsady obejmującej przeciwstawne postaci: „Apokaliptyczny Jinnah i łagodny Rajkumar, ten, kto zdobywa ziemię i ten, kto ją traci. Przez te dwie przeciwne gwiazdy dostrzec można wspaniałą tajemnicę: kto wie, czy Rajkumar nie nawiedza Jinnaha, tak jak każdy z nas jest nawiedzany przez swoje przeciwieństwo".

Kolejnym z wątków pobocznych były dzieje wspominanego wieśniaka z Pendżabu - Rajkumara ${ }^{17}$. Historia ta przeplatała się $\mathrm{w}$ wielu miejscach Indiady: w 2 scenie I aktu, 2 scenie III aktu, 3 scenie IV aktu i 3 scenie V aktu. W pierwszym obrazie Rajkumar przybył do Gandhiego z prośbą o radę. Nie wiedział co zrobić, żeby nie zabić sąsiada, który kradł ziarno z jego pola. Oczekiwanie

16 Nathuram Godse to postać, która była obecna w pierwszej wersji 4 sceny V aktu dramatu Cixous. W przedstawieniu Mnouchkine scena ta została skrócona między innymi o repliki zabójcy Gandhiego. Godse pojawił się natomiast w wersji Indiady sfilmowanej przez Sobela.

17 Jedną z inspiracji dla tej postaci był chłop z Biharu Raykumar Chukla. 
na rozmowę z Mahatmą trwało kilka lat i zmieniło życie Rajkumara. Jednak w 3 scenie IV aktu, kiedy już po podziale Indii sąsiad Pendżabczyka muzułmanin Siddiki zamordował mu rodzinę i ukradł dom, Rajkumar w odwecie zabił jego syna. W 3 scenie V aktu wieśniak spotkał nareszcie Gandhiego:

Gandhi: - „Rajkumar, tym razem idę z tobą. Chodźmy do Pendżabu. Dzień nadszedł".

Rajkumar: — „Dzień przeszedł, Mahatma. Nie przychodzę do pana, bo jest już za późno [...]".

Gandhi: — „Rajkumar, proszę cię przebacz mi”.

Rajkumar: — „Jak panu wybaczyć? Nie mam już niczego i nikogo. Mówię w imieniu pięciu milionów Pendżabczyków, którzy nigdy nie sądzili, że Mahatma Gandhi ich opuści. Co zrobić, żeby panu przebaczyć. Nikt nie może mi teraz odpowiedzieć [...]. Zabijając, zabija się także samego siebie. Doświadczyłem tego, gdy zabijałem syna Siddiki. Teraz jestem w połowie umarły. Nie jestem już z tego świata i nie wiem, gdzie szukać człowieka" (Cixous 1987a, s. 184, 186).

Z wątkiem Rajkumara w 2 scenie III aktu i w 3 scenie IV aktu łączyły się losy Bahadura i niedźwiedzicy Moony Baloo ${ }^{18}$. Jej pojawienie się na scenie nierzadko wzbudzało efekt komiczny, ale główne znaczenie tej zwierzęcej bohaterki pozostawało zupełnie inne. Wprowadzenie niedźwiedzicy, postaci nie-człowieka, pomogło zaakcentować jedno z kluczowych pytań Indiady: „Kim jest człowiek?”, „Kim jest zwierzę?”. Jako że „ani barbarzyństwo, ani człowieczeństwo nie występują dokładnie tam, gdzie się sądzi, że się je spotka" (Boucais 1986, s. 60). Wezwanie Gandhiego stanowiące motyw jego misji:

Gandhi: — „Trzeba stawić czoło bestii. Odwagi! Zaufajmy człowiekowi” (Cixous 1987a, s. 132).

Wielokrotnie powtarzane pojawiało się w finale. Przejmowała je także Haridasi, która metaforycznie, a zarazem konkretnie, określała problem stojący na drodze ku temu, co ludzkie:

Haridasi: - „Droga do człowieka jest przegrodzona przez świątynie i meczety” (Cixous 1987a, s. 182).

Bahadur, „samotny i owdowiały” po zabiciu ukochanej Moony, zastanawiał się:

Bahandur: - „Kto może dziś powiedzieć, gdzie jest zwierzę, a gdzie człowiek?” (Cixous 1987a, s. 191).

Niedźwiedź, w symbolice ludów Syberii i Alaski postrzegany jako przodek rodzaju ludzkiego, nazywany bywał „Dziadkiem” i łączony z pamięcią. Z kolei w mitologii greckiej towarzyszył Artemis i jako zwierzę księżycowe, które mogło być potworem bądź ofiarą, stawał się tym, kto składa ofiarę, bądź nią

18 Anne Neuschäfer we wprowadzeniu tego wątku widziała nawiązanie do prozy Rudyarda Kiplinga, a w szczególny sposób do Kima (1999) (por. www.lebacausoleil.com). 
jest. Jung postrzega niedźwiedzia jako niebezpieczny aspekt nieświadomości (Chevalier, Gheerbrant 1992, s. 717). „Wszyscy dbaliśmy o Misia, jak o siebie. Potem «dorośliśmy». Porzuciliśmy, a następnie zapomnieliśmy o Misiu, matce, dzieciństwie, przywiązaniu i zaufaniu. Moona Baloo to nie tylko przytulanka. To wielka, łagodna, silna, dzika część naszej tajemnicy bycia człowiekiem. To nie wilk, ani lew" - pisała Cixous (1988, b.n.s.) w komentarzu do Indiady.

Moona Baloo była „rozmówczynią” nie tylko Bahadura, ale także Gandhiego. Niektórzy krytycy w niedźwiedzicy widzieli alter ego tego ostatniego. Bapu czynił z niej wspólniczkę, z którą wyruszył, by uspokoić Indie:

Gandhi: - „Wiesz Moono, co moje Indie ostatnio zrobiły? Same wsadziły łapy w krew. Wielkie zadrapanie w Kalkucie! Jakie szalone! A jeśli rozpoczną na nowo?

Nie! Powstrzymamy je, dobrze? Nawet tygrys lubi pieszczoty. Jeśli się go drapie w dobrym miejscu, staje się kociakiem.

Ech! Muszę ich ugłaskać wszystkich, te moje tygrysy, małe i wielkie, hinduskie i muzułmańskie. Chodź Moona, idę na obchód mojego królestwa, chodź ze mną zrobić inspekcję uliczek serca [...].

Oko za oko, ząb za ząb! Słyszysz ich Moona? Co macie zamiar tu zrobić [...]? Rozsiać głupotę i bestialstwo? Piękne będą nasze Indie bez oczu, bez zębów, bez serca, bez człowieczeństwa, jeśli Bogowie pozwolą działać zwierzętom [...]" (Cixous 1987a, s. 125, 128)

Jednak bestii, w jaką zamieniły się Indie, nie uspokoił marsz Gandhiego i Moony, „dwojga dzieci, jednego porośniętego sierścią, drugiego zupełnie nagiego" - jak określiła tę parę Haridasi. Masakry w Delhi powstrzymał w finale dopiero post Bapu.

Od pierwszego pojawienia się na scenie Moona Baloo stanowiła sejsmograf nastrojów społecznych i przejmowała emocje ludu. Wybuchem złości reagowała na pierwsze, wyrażone wprost, żądanie podziału Indii, sformułowane przez Jinnaha. W 3 scenie II aktu nad szałem zwierzęcia potrafil jeszcze zapanować jego opiekun, ale w finale i on nie kontrolował już furii Moony. Tak jak Gandhi i Nehru, Bahadur był bezsilny w obliczu epidemii zła. We własnej obronie musiał zgładzić uosobienie „wielkiej, łagodnej, silnej, dzikiej części tajemnicy bycia człowiekiem".

\section{WYPOLEROWAĆ SCENĘ SERCA LUDZKIEGO}

W Indiadzie uniwersalny problem separacji został odbity jak w lustrze w mozaice jednostek i wątków pobocznych. Różnorodność podkreślana w wielu planach pozwoliła na ukazanie złożoności istoty ludzkiej oraz odmiennych aspektów człowieczeństwa. Jedynie Indie - kraj tak bogaty i barwny - mogły dostarczyć tylu tak różnych, silnych duchem bohaterów. Wybór innego kraju jako sceny dla historii podziału, zranionej miłości, choć możliwy, z dużym prawdopodobieństwem okazałby się mniej trafny i skuteczny. Pavis (1990, s. 219) 
pisał o sprzeczności między moralnością uniwersalną i humanistyczną tekstu a jej przedstawieniem etnologicznym, typowo hinduskim. Ale przecież to różnorodność etnologiczna pozwoliła Mnouchkine jeszcze bardziej podkreślić uniwersalność prezentowanego problemu.

Kluczem do przedstawienia, pozwalającym na ustanowienie relacji między ogólnym i jednostkowym, uniwersalnym i poszczególnym, były kontrasty. „Indyjskość” istniała na scenie dzięki nim. Indie stanowią ich uosobienie. Podróżujący na subkontynet często zauważają, że to, co piękne, jest tam najpiękniejsze, a to, co straszne, najpotworniejsze. Barwy, zapachy, światło najbardziej intensywne, podobnie jak ból, mrok i beznadzieja. Tak duchowość, jak i okrucieństwo osiągają ekstrema.

Architektura wyznaczała ramę dla wydobycia różnic. Przestrzeń stawała się instrumentem rozumienia akcji scenicznej i jedną z podpórek dla gry aktorów. Pozwala na jej metaforyzację (Corvin 1976, s. 65). Scena i widownia ponownie zostały ustawione frontalnie. W jednym $z$ wywiadów udzielonych przy okazji premiery Mnouchkine mówiła: „Nie chcę już przemieszczających się dekoracji. Czego miało mnie to nauczyć, już mnie nauczyło. W tym spektaklu tekst ma taką wartość, że potrzebuję widzieć i słyszeć aktorów" (wypowiedź w: Temkine 1987, s. 10).

Przestrzeń z prawej strony sceny zajmowali muzycy. W Indiadzie Jean-Jacques'owi Lemêtre'owi towarzyszyli Corrine Hache i Pierre Rigopoulos. Prostokątna scena stanowiła rodzaj agory pośrodku wyłożonej białymi płytami przypominającymi marmur lub alabaster. Podczas spektaklu polerowali ją aktorzy odgrywający służących. Lśniąca, jasna podłoga została umieszczona na postumencie $z$ ciemnoczerwonych cegieł. Biel płyt i jasny kolor ścian kontrastowały z barwą podstawy. Pavis (1990, s. 200) zwrócił uwagę na podobieństwo przestrzeni Indiady do Tadż Mahal - siedemnastowiecznego mauzoleum w Agrze, w którym marmurowe płyty odbijają światło. Obok nawiązań do architektury Indii w aranżacji sceny można było odnaleźć inspiracje duchowe. Polerowana w przedstawieniu scena kojarzyć się mogła z praktykami wewnętrznych oczyszczeń występującymi w każdym systemie religijnym, tak ważnymi na przykład w sufizmie: „Działalność [sufich] nie polega na repetycji książek i nauczaniu, lecz na polerowaniu serc z rdzy, tzn. chciwości, zawiści, skąpstwa i złośliwości. Serce jest jak wypolerowane zwierciadło, które nieustannie promieniuje odbite $\mathrm{w}$ nim obrazy. Jednocześnie każda rysa na sercu jest źródłem aberracji, które są również wyraźnie widoczne. $\mathrm{Ci}$, którzy wypolerowali swoje serca, zdołali uwolnić się od złudnych barw i zapachów. I dlatego też są w stanie widzieć, czuć i rozumieć piękno" — pisał Dżalaluddin Rumi (cyt. za: Lefort 1995, s. 99). Sceną niszczących człowieka podziałów, bratobójczej wojny były jednocześnie Indie — kraj przypominający kształtem serce ludzkie — oraz serce każdego człowieka - aktora i widza. Oczyszczanie sceny, polerowanie serca, stanowiło niezbędną praktykę na drodze odkrywania i rozwijania istoty człowieczeństwa. 
Tadeusz Kowzan w tekście Teatr jako uprzestrzennienie literatury podkreślał, że $z$ wielomateriałowością zjawiska teatralnego wiąże się „wymienność znaków ukształtowanych z różnych tworzyw, znaków należących do odrębnych systemów [...] wymienialność znaków teatralnych i ich zdolność do przekształceń modyfikuje charakter metonimii i metafory w spektaklu. W tekście literackim metafora czy metonimia stanowi, jak pisze Riffaterre, «przeniesienie, zastąpienie jednego elementu znaczącego [...] innym, przy zachowaniu tegoż elementu znaczonego [...], ale zawsze $\mathrm{w}$ tym samym tworzywie, natomiast $\mathrm{w}$ toku przedstawienia przeniesienia owe mogą się dokonywać pomiędzy różnymi tworzywami» [...]" (Kowzan 1991, s. 123). Mnouchkine dzięki aranżacji przestrzeni dokonała specyficznego przeniesienia. Przeniosła, czy raczej rozciągnęła, jednocześnie dosłowne i metaforyczne rozumienie tematu na przestrzeń. Dokonała w ten sposób jego hiperbolizacji. W Indiadzie, ale także przez jej przestrzeń, jej przestrzenią, Théâtre du Soleil opowiadał historię o oczyszczaniu serc ludzkich. W bólu i w radości, w nadziei i w momentach rozpaczy, w sercach kontynentów, ale i konkretnych kobiet oraz mężczyzn toczyła się podobna walka.

Boki głównego tarasu, podobnie jak ciągi niewielkich schodów, zamykających scenę $z$ trzech stron, zostały wyłożone cegłą. Schody dzieliły przestrzeń sceniczną na różniące się poziomami i wielkością „półki”. I wyznaczały poszczególne miejsca akcji. Prości ludzie najczęściej pojawiali się po bokach sceny, centrum zostało zarezerwowane dla polityków. Każda grupa zajmowała odrębną przestrzeń ${ }^{19}$. Szerokie schody składające się z kilku stopni łączyły także widownię ze sceną. Tutaj, na granicy dwóch światów, siadywał Gandhi rozmawiając z Nehru, Kasturbaï i Rajkumarem. Nagi Bapu podpierał niekiedy głowę ręką w pozycji przypominającej figurę świątka, Chrystusa Frasobliwego. Po centralnych schodach wchodzili na scenę aktorzy oraz wjeżdżały po ruchomej kładce riksze przykuwające uwagę widzów pięknem i delikatną elegancją form. Pojazdy stanowiły rodzaj ażurowych, ruchomych konstrukcji. Ciągnięte przez rikszarzy, ubranych w jednakowe białe spodnie i purpurowe bluzy ze złotymi obszyciami, przypominały nieziemskie rydwany. Rikszami wjeżdżali i zjeżdżali ze sceny politycy, zazwyczaj odbywało się to wśród wrzawy i radosnych dźwięków jak w 3 scenie II aktu, podczas konferencji w Simla. W finałowej scenie wśród odgłosów pojedynczych gongów rikszami zwożono ze sceny ciała pomordowanych: Imy, Ahmada, Strażnika grobu Świętego Sufiego. Ciało niedźwiedzia słudzy znosili $\mathrm{w}$ płachcie. $\mathrm{W}$ tej scenie zmieniało także barwę ciepłe światło Południa, spływające z góry, zza ozdobionej gwiaździstymi motywami białej materii. Stawało się ono chłodne, trupio blade. Jasna przestrzeń, świetlisty parkiet polerowany $\mathrm{w}$ toku przedstawienia, kojarzony z niebiańską domeną, napełniał się cmentarnym zimnem. Ostatnia scena, mimo zapewnień

$19 \mathrm{~W}$ filmie Sobela rozmowy rikszarzy często odbywały się w garderobie umieszczonej pod siedzeniami dla widzów. 
Haridasi, że Gandhi „jest nieśmiertelny i powrócił do Bogów, którzy go nam wypożyczyli", ukazała najpełniejszy wymiar tragedii podziału.

Główny element stałej dekoracji stanowiły schody. Rytmizowały przestrzeń, wiązały się z ruchem i dynamiką. Wyznaczały obszar mediacji między tym, co na górze, a tym, co na dole, światem polityków i zwykłych ludzi, między aspektem wysokim i niskim obecnym w każdym człowieku i całym makrokosmosie. Dobrochna Ratajczakowa (1999, s. 10) pisała, że schody stworzył „gest przekroczenia ludzkiego wymiaru, dążenie do wyjścia poza bezpieczny układ horyzontalny, do przekształcenia przestrzeni i czasu, jednoczesnego ich rozciągnięcia i pomniejszenia, a zarazem złączenia: rozciągnięcia w transcendencję, pomniejszenia do podstawowej, zwierzęcej egzystencji [...]”. Odpowiedź na pytanie „Kim jest człowiek?”, stale powtarzane w Indiadzie, została wpisana w przestrzeń. Człowiek to istota rozpięta między tym, co transcendentne, a tym, co zwierzęce. Nie tyle stanowi pośredni szczebel w tej drabinie, ile posiada zdolności przechodzenia i wyboru między tym, co wysokie i niskie. Tył sceny zamykała jasna ściana z dwojgiem drzwi - dużymi umieszczonymi centralnie i zarezerwowanymi dla polityków oraz małymi znajdującymi się z prawej strony i prowadzącymi do „zwykłych” domów. Drzwi, ozdobione okalającymi je złotymi ornamentami, zasłaniała biała materia. Przylegał do nich wąski pomost $z$ cegieł zamykający scenę. Główne wejście w przestrzeń gry prowadziło z garderób pod ławkami widowni i przypominało tunele na stadionach. Stamtąd wyjeżdżały riksze, wchodziły pojedyncze postaci i całe grupy.

Przestrzeń była jednocześnie ascetyczna i harmonijna. Ekonomia użytych środków wizualnych dzięki staranności wykonania przywoływała bogactwo starej tradycji. Pozostawiała jednocześnie widzom wolność niezbędną do pobudzenia pracy wyobraźni i umożliwiała im skoncentrowanie się na treści sztuki. Przenośne elementy oraz zmiany oświetlenia wyznaczały miejsca akcji - sceny w więzieniu oraz sekwencje z mścicielami, braćmi Sen, rozgrywały się $\mathrm{w}$ mroku. Wnoszone na głowach służących materace, duże białe wałki, poduchy, zrolowane dywany $\mathrm{w}$ orientalne wzory rozkładane na oczach widzów, rama przypominająca warsztat tkacki, na którym Gandhi splatał nici wyznaczały przestrzeń wnętrz. Z kolei parasole, riksze, podróżne zawiniątka wiązały się z zewnętrzem. Kilka dźwięków, odpowiednie światło i ruch kryjących się przed deszczem postaci wystarczyły, by zasugerować nadejście monsunu.

Jasna i pusta marmurowo-ceglana konstrukcja stanowiła tło dla kostiumów. W strojach mężczyzn polityków najczęściej spotykanymi barwami były biel i czerń. Jinnah występował w białym garniturze, Liaquat Ali Khan związany z Ligą Muzułmańską w czarnym surducie, a Nehru w białym. Barwne motywy pojawiały się z rzadka. Tuniki i surduty charakteryzowały się prostotą oraz dokładnością kroju i kontrastowały z lśniącymi sari Sarojini Naïdu i Kasturbaï. Czytelne makijaże pozwalały natychmiast rozpoznać Gandhiego i Nehru. $\mathrm{W}$ przypadku innych postaci były równie dokładne. Makijaże polityków miały 
swoje źródło w marzeniach aktorów o „fotograficznej rekonstrukcji rzeczywistości” (Ubersfeld 1981, s. 68). Jednak nieznajomość pierwowzorów nie pozwalała większości widzów na porównanie bohaterów Indiady z „oryginałami”. Ubiory „zwyczajnych ludzi” były zazwyczaj wielowarstwowe, o stonowanych barwach: beżu, brązu i szarości. Przykuwały uwagę kolorowe stroje muzułmańskich kobiet. Kostiumy i makijaże pozwoliły na wyróżnienie określonych typów społecznych i etnicznych za cenę pewnego uogólnienia.

\section{MOZAIKA KONTRASTÓW}

Przedstawienie charakteryzowało się wizualnym pięknem. Ruch istniał na scenie w sposób choreograficzny. Szczególnie efektowne były wjazdy głównych bohaterów rikszami na tle ostrej, melodyjnej muzyki. Przemieszczenia postaci i następstwo scen wyznaczało rytm spektaklu, który także opierał się na kontraście. Stanowił on podstawową zasadę kształtującą Indiadę, rozpoznawalną zarówno na płaszczyźnie fabuły, jak i muzyki. Różnym postaciom towarzyszyły odmienne lejtmotywy: Gandhiemu dzwoneczki, Nehru rzewna cicha melodia. Słowa mówiące o „podziale”, „separacji” za każdym razem punktowane były muzyką. W przełomowych momentach, takich jak zakończenie wojny, postaci wyrażały radość pieśnią, piskiem i krzykiem. Kontrasty dostrzegalne były także w kostiumach, gestach, ruchu, sposobach wykorzystania głosu przez poszczególnych aktorów.

W wydobywaniu różnic pomagała jasna ascetyczna i odbijająca światło przestrzeń, stanowiąca rodzaj pudła rezonansowego, oraz „oczyszczony”, charakteryzujący się dużą przejrzystością i dynamiką dialog sięgający po różne formy literackie. Dominowały krótkie wypowiedzi postaci, składające się z kilku zdań. Odpowiedniki stychomytii nie występowały. Długie monologi, zazwyczaj wyrażone $\mathrm{w}$ formie prozy poetyckiej lub białego wiersza zapowiadały przełomowe wydarzenia, często wprowadzały patetyczny, wizjonerski nastrój. Jedne i drugie płynnie przeplatały się ze sobą. „Oczyszczony” dialog z 4 sceny III aktu występował obok poetyckiego monologu Mountbattena rozpoczynającego 1 scenę IV aktu:

Patel: - „Londyn przyspiesza Historię. Zastępca króla został odwołany, jego następca przybędzie za trzy dni”.

Nehru: — „Kto to?”

Patel: — „Mountbatten. Mamy szczęście!”

Gandhi: — „Jeszcze jeden zastępca króla, a ten mówi o szczęściu!”

Patel: - „Ten będzie ostatni Bapu, Anglia to obiecała. Opuszcza nas! Nasz los rozstrzygnie się niebawem”.

Nehru: — „Kiedy?”.

Patel: — „Najpóźniej za rok”.

Nehru: — „Rok?! Tak szybko! Rok? Za rok, więc w Delhi my sami, bez Anglików. Ach! Widzę już naszą flagę łopoczącą na wietrze nad Czerwonym Fortem” [...]. 
Mountbatten: - „O India, nabrzmiała od burz i cudów,

Drżąc czekasz ciosu

Jak zwierzę, które zarazem zna i nie zna swego przeznaczenia.

Pozwól mi spędzić ostatnią noc mojej niewinności

$z$ tobą

Jutro będę bezlitosny [...].

Być ostatnim królem tego Imperium!

Koronowanym pozbawionym korony

I być jednocześnie akuszerem i katem!

Ach! Dlaczego Mountbatten nie przybył rok

wcześniej! Oszczędziłbym Indiom tego noża.

Czyżby to była więc sprawa spóźnienia? [...]

Jutro nie będę mógł niczego zrobić, jak tylko objawić

Wasze nieszczęście. I rozdzielić między was

kawałki zamętu.

Osiem nocy, w których bujały jak gałęzie

akacji miliardy twoich blasków ponad Piekłem

i Niebem

Ty i ja wiemy, że były uczynione $z$ marzenia

Mahatmy Gandhiego.

Myślę o nim, antycznym bezzębnym bóstwie, starej matce

Bez sutków, ostatnim dowodzie na istnienie

bogów i na ich niemoc, aby zmusić do uznania własnych

proroków w naszym politycznym wieku.

Biedny stary ptaku pozbawiony skrzydeł, wybacz mi, jeśli ja

także ze wszystkimi twoimi przyjaciółmi i nieprzyjaciółmi i ja

przyczynię się jutro do twojej porażki" (Cixous 1987a, s. 147-148).

Kontrasty w Indiadzie były również widoczne na poziomie fabuły, w której sekwencje obrad polityków (1 scena I akt, 3 scena II akt, 2 scena IV akt) zostały zestawione ze scenami rozgrywającymi się wśród ludu. Dyskusje przedstawicieli Ligi Muzułmańskiej (1 scena III aktu) pozostawały w opozycji do działania Gandhiego na rzecz biednych i niedotykalnych (2 scena III aktu). Wyraźne przeciwstawienie było widoczne już $\mathrm{w}$ pierwszej scenie spektaklu, w której po przegranych wyborach Ligi Muzułmańskiej politycy Kongresu podejmowali próby unii z Ligą:

Nehru: — „Uznaję, że Liga jest partią. Respektuję was jako taką. Pobiłem was jako taką. Zwyciężyłem was jako taką. Politycznie [...]".

Jinnah: - „Nie prezentujcie już waszych muzułmanów przeciwko naszym muzułmanom. Wy nas podzielicie. Zostańcie na swoim brzegu, a my na swoim. I wykąpiemy się w jednej rzece".

Nehru: - „[...] Dla was muzułmanie, dla nas hindusi? Mamy podzielić wszystkich Hindusów w klatki religijne? [...]. O czym my mówimy? O polityce czy o religii? W polityce, Jinnahu, rzucam panu rękawicę. Jeśli chodzi o religię, więcej pana nie słucham. Jestem człowiekiem tego czasu. Jestem laikiem. Jestem Hindusem. Chcę mówić z Hindusem. Jeśli nie, nie powiem już nic więcej”. 
Azad: — „A ja, który jestem muzułmańskim Hindusem, wierzącym w religii, laikiem w polityce, gdzie mam pójść w waszych Indiach o dwóch brzegach? Powinienem się przeciąć na pół? [...]" (Cixous 1987a, s. 27-30).

Ostatecznie negocjacje i poszukiwanie wspólnego stanowiska okazały się bezowocne. Zasygnalizowane postawy i sposoby reakcji charakterystyczne dla poszczególnych postaci - nieustępliwość Jinnaha, porywczość i zdecydowanie Nehru, próby mediacji Azada - zostały rozwinięte w spektaklu. Niemożliwość znalezienia kompromisowego rozwiązania w pierwszej scenie zapowiadała katastrofę $\mathrm{w}$ finale, oznaczającą krwawe zamieszki i podział kraju.

Esencję kontrastów istniejących w Indiadzie stanowiła para Gandhi - Jinnah. Postaci te różniły się cechami fizycznymi (włosy/łysina, zęby/ich brak), strojem (zachodni garnitur/półnaga postać owinięta zgrzebną płachta), sposobem poruszania (sztywność i energiczność kroków Jinnaha/dreptanie Gandhiego), postawą ciała (Jinnah, który sprawiał wrażenie silnego mężczyzny, często przyjmował pozycję leżącą oznaczającą chorobę/słaby, drżący Gandhi pełen werwy, podróżował pieszo). Bapu mówił o tych różnicach wprost:

Gandhi: — „Tutaj, przede mną jest inny i nic nie jest takie jak ja! Na przykład pan i ja, czy można wyobrazić sobie ludzi bardziej różnych? Pan z pięknymi włosami, pięknym krawatem, garniturem, wypastowanymi butami i wszystkimi zębami. A ja bez. Bez niczego. Bez włosów, bez garnituru, bez zębów [...]. Co nas przyciąga $\mathrm{w}$ świecie? Tajemnica. Inna płeć, inna religia, inna istota ludzka [...]" (Cixous 1987a, s. 82).

To, co odmienne, stanowiło dla Gandhiego wartość, świadczyło o ludzkim bogactwie. Bapu i Jinnah, tak różni fizycznie, prezentowali również krańcowo przeciwstawne wizje świata i wartości. Już pojawienie się ich obok siebie robiło na widzach elektryzujące wrażenie. Dwie sceny, w których dochodziło do bezpośredniej konfrontacji bohaterów - 2 scena II aktu oraz 2 scena aktu IV, należały do najbardziej przejmujących. Siła ich oddziaływania wynikała nie tyle $z$ dynamiki akcji, szybkich replik, ile z przeciwstawienia rozbudowanych opinii, niekiedy pointowanych wyrażoną jednym słowem lub jednym zdaniem negacją. Podczas pierwszego spotkania postacią dominującą był Gandhi, w drugim starciu to Jinnah zajmował pozycję uprzywilejowaną. Obie sekwencje pozostawały w silnym związku. Druga stanowiła rozwinięcie pierwszej. Efekt obu był podobny.

W 2 scenie II aktu Gandhi odwiedzał Jinnaha w jego domu w Bombaju. Biały wygodny materac podparty dużym wałkiem tej samej barwy wyznaczał miejsce spotkania. Słowa Gandhiego, wypowiadane na tle łagodnej muzyki i kierowane bezpośrednio do widzów, stanowiły hymn miłości dwóch narodów. Pieśń miłosna Bapu była wypowiadana na łożu. Gandhi nie tylko sławił miłość, ale także dostrzegał związane z nią problemy, na które wskazywał lekarstwo. Jego pełne wiary i euforii wypowiedzi przerywał Jinnah krótkimi frazami, przeczącymi opiniom przedmówcy. Za każdym razem jednak Gandhi powracał do te- 
matu miłości, akceptacji innego, ubogacającej różnicy. Podejmował swoją pieśń wielokrotnie, mimo kolejnych sprzeciwów rozmówcy. Ostatecznie rozsierdziła Jinnaha wizja rozdzielonych dwóch narodów pozostających pod wspólnym dachem. To wówczas konflikt wybuchnął ze zdwojoną siłą:

Jinnah: — „Miłość! Miłość! [...] Niech pan mi nie opowiada swoich marzeń! Ludzie nie kochają się. Nie pokochają się nigdy. Indie z pana marzeń nie istnieją. Niech pan otworzy oczy [...] Niech pan spojrzy, pan jest nagi. I sam. Wszyscy upadamy, oddzielnie".

Gandhi: - „Otwieram oczy, gwiazdy spadają, a niebo jest nadal równie błyszczące, upadamy w ręce tego samego Boga. Widzę Indię [...]. Nie widzę Pakistanu".

Jinnah: — „Niech pan stąd idzie [...] Nie mówimy tym samym językiem. [...] Pan nie chce słyszeć o podziale. Podział jest jedynym słowem, które chcę wypowiadać. Uciszmy się więc. Zaakceptujmy lojalnie wyrok rzeczywistości. Jesteśmy nie do zaakceptowania dla siebie nawzajem. I bid you adieu!".

Gandhi: — „Nie! Niech pan nie odchodzi! Jeśli pan odejdzie... Uczepię się pana, pana płaszcza! [...] Odszedł! [...]" (Cixous 1987a, s. 83-84).

Kończąc swoją ostatnią replikę, Jinnah opuszczał przestrzeń gry. Gandhi na próżno próbował własnym ciałem zagrodzić mu drogę. Wyjście Jinnaha z domu antycypowało exodus muzułmanów do Pakistanu.

W 2 scenie IV aktu Gandhi ponownie starał się przekonać szefa Ligi Muzułmańskiej. Pojawiał się nagle, nieoczekiwany w chwilę po tym jak Nehru i Jinnah, mimo prób mediacji Mountbattena, zaakceptowali zasady podziału kraju. Gandhi wchodził na scenę bramą z garderoby. Jego pojawieniu się towarzyszyły niebiańskie odgłosy dzwoneczków. Owinięty był białą płachtą i przypominał postać Chrystusa z wizerunków Ecce Homo. Nehru zbiegał po starca i pomagał mu wejść na scenę, a następnie sadzał na tronie, ustawionym w centralnym miejscu. Oto nagi król, bezbronny i wystawiony na cierpienie przez najbliższych. W przejmującym dialogu wydobyte zostały nawiązania do Biblii:

Gandhi: — „Nakrywam was z mieczem w dłoni, już podniesionym i z zamkniętymi oczami, żeby nie widzieć zbrodni, którą popełniacie [...]”.

Patel: — „Nie ma innego wyjścia niż Podział”.

Gandhi: — „Tę piosenkę już znam. Znam także piękniejszą! To piosenka Salomona. Posłuchajcie mnie: «Wasza Wysokość, proszę niech pan odda żywe Indie panu Jinnahowi, niech ich pan nie uśmierca! Na miłość boską, niech ich pan nie rozłupuje» $[\ldots] "$.

Jinnah: — „[...] Ocalcie matkę, zabijcie dziecko, krzyczy fałszywy prorok”.

Gandhi: — „Przeciwnie! Niech pan wszystko bierze! Wszystko przejmie!”.

Jinnah: - „Pan wierzy, że zdoła pan kupić Jinnaha [...] Pan chce uwięzić tego, który nie jest już z tego świata. Nie widzi pan, że jestem umarły? Jestem martwy dla Indii i wyzwolony! [...] To mój duch stawia panu czoło [...] Panowie pozwólcie odejść temu ciału, które mi służy za pozór. Po co zatrzymywać mój cień jako zastaw? Popatrzcie na Zachód, to wielkie słońce, które przeziera przez chmury, to jajo ognia, to Pakistan, mój twór, moje dzieło, moja planeta! To tam 
idę i zabieram ze sobą połowę Bengalu, połowę Pendżabu, Sind i Granicę! Nie będę już dyskutował. Niech pan mnie puści. Niech pan się mnie nie uczepia, bo zabiorę pana do mojego grobu!" (Cixous 1987a, s. 160-162).

Żadne z działań Gandhiego, ani płacz, ani towarzyszące jego słowom ogołocenie fizyczne (Bapu, próbując oddać całość Indii Jinnahowi, zdejmował okrycie z pleców), ani pochylenie się do stóp przeciwnika, nie spowodowały zmiany jego decyzji. Jinnah odchodził podpierając się laską. Już wówczas gdy pozostawał na scenie, wydawał się nieobecny, całkowicie pogrążony w swojej wizji. Nehru ze łzami w oczach odciągał płaczącego Gandhiego, obejmując go, wypowiadał mocnym, choć łamiącym się głosem swoje repliki. Towarzyszył im lejtmotyw powracający każdorazowo w chwili marzeń polityka o wolnych Indiach:

Nehru: — „Bapudżi, żaden człowiek nie podąży za tobą tą drogą, która, aby zdobyć niebo, pozbawia się ziemi. Jesteśmy stąd, z niskości. Chcemy Indii indyjskich, oświeconych, laickich, socjalistycznych. Oddać je Lidze byłoby grzechem. Wasza Wysokość, chcę Podziału. Bez radości, bez dumy, bez wahania" (Cixous 1987a, s. 162).

Gandhi jeszcze próbował bronić swoich wizji, frazy wypowiadał z bólem i ze łzami na tle rzewnej muzyki. Schodził ze sceny, drepcząc samotnie. Był bezbronny i całkowicie bezradny. W tym momencie jawił się jako pokonany. W ostatniej scenie V aktu widzowie poznali go jednak jako tryumfatora, który postem powstrzymał zamieszki w Delhi. Leżąc na małym dywaniku mówił wówczas:

Gandhi: — „Żebyście wiedzieli, jak słodko jest narodzić się w wieku siedemdziesięciu ośmiu lat. Ba! Zobacz, jaki świat jest dobry. Spędza się tu czas na porzucaniu nadziei i na ufaniu od nowa. Chmury zakrywają słońce, ale to tylko chmury. W końcu słońce przez nie prześwieci. Pokój jest wysoko na niebie tego ranka! Czy to widać, że ja się śmieję?" (Cixous 1987a, s. 205).

Po raz ostatni Gandhi schodził ze sceny w towarzystwie zmarłej Kasturbaï i Indera. Dźwięczny i niepokojący głos dzwonu zwiastował nieszczęście. Na pustej scenie na tle odgłosów gongu pozostawali Haridasi i Inder. Po chwili wbiegali na nią Nehru, Sarojini, Azad i Patel. Repliki małych i wielkich postaci wyrażone symetrycznie ponownie zostały zderzone. Stanowiły ostatni kontrast, a zarazem dopełnienie pojawiające się w Indiadzie. Wszystkie frazy wypowiedziane zostały do publiczności:

Haridasi: — „On nie umarł Inder, stał się nieśmiertelny. Powrócił do bogów, którzy go nam wypożyczyli”.

Inder: - „Umarł. To był człowiek, człowiek absolutny [...] Pozostawił mnie samego, kroczącego za nim w ciemności. I teraz, kto mnie pokocha? Kto mnie wesprze? [...]".

Nehru: — „Mahatma Gandhi umarł. Jego zabójcą jest Hindus”. 
Azad: — „My, którzy jesteśmy resztkami jego wieku, śladami jego kroków, radujmy się pośród łez, gdyż widzieliśmy śmiech najlepszego z ludzi. Widzieliśmy jak niemożliwe uśmiecha się do nas" (Cixous 1987a, s. 206-207).

Théâtre du Soleil to najdłużej działający pozainstytucjonalny francuski zespół teatralny. Ariane Mnouchkine i jej współpracownicy potrzebowali wielu lat, by określić rolę i funkcję swojego teatru, wypracować podstawy języka scenicznego, poruszyć tematy i odkryć formy rozwijane $\mathrm{w}$ dojrzałych przedstawieniach. W połowie lat siedemdziesiątych stało się oczywiste, że artyści z Cartoucherie, podążający za przykładem Molière'a i zgodnie z zaleceniami Jacquesa Copeau, pragną tworzyć „teatr swojej epoki”. Takie zadanie wiązało się ściśle ze społecznym zaangażowaniem zespołu, który zamierzał zawsze stawać $w$ obronie bezbronnych, represjonowanych, zapomnianych osób, narodów, dóbr kultury i innych wartości. Oczywiście, reżyserka broniła się przed postrzeganiem jej twórczości li tylko jako działalności społecznej.

„Dramaturgiczny przełom” w pracy zespołu nastąpił na początku lat osiemdziesiątych dzięki tekstom napisanym przez Hélène Cixous specjalnie na deski Cartoucherie: Straszna, ale niedokończona historia Norodoma Sihanouka, króla Kambodży (1985), Indiada, albo Indie $z$ ich snów (1987), Wiarołomne miasto, albo przebudzenie Erynii (1993) oraz Bębny na tamie (1999). Théâtre du Soleil potrafił w nich ukazać własną wizję współczesnych dziejów, przedstawić publiczności autorską „historię świata”. Konkretne problemy polityczne obecne na scenie uświadamiały widzom „bliskość” pozornie odległych wydarzeń.

Mnouchkine wielokrotnie $z$ oburzeniem odpowiadała na zarzuty dziennikarzy, że historia współczesnej Kambodży czy Indii jest odległa od zainteresowań publiczności. Podczas prób Indiady zaś podkreśliła, że choć krytycy zakwalifikują ten spektakl jako przykład teatru historycznego, $\mathrm{w}$ istocie jest to przedstawienie, które dotyczy osobiście zespołu i wszystkich jego członków $z$ osobna. Społecznie zaangażowane przedstawienia Théâtre du Soleil jednocześnie służą ukazaniu zmagań odwiecznych sił, złości bogów, ludzkiej żądzy władzy, obojętności, współczesnej erozji świadomości. Hélène Cixous, odwołując się w swoich dramatach do form podstawowych dla dramaturgii europejskiej i źródeł orientalnych, wydobywa ze współczesnych tematów wymiar mitów. Oparte na ich podstawie spektakle zakorzenione we współczesności poruszają problemy społeczno-polityczne, a jednocześnie nigdy nie przestają być tworami bogatej wyobraźni. Inspiracje orientalne chronią przedstawienia Mnouchkine przed schematami i stereotypowym przedstawieniem historii, pomagają wyrazić jej aktualność i złożoność obejmującą różnorodne aspekty istnienia. 


\section{BIBLIOGRAFIA}

Boucais Luc, 1986, L'histoire terrible mais inachevée de Norodom Sihanouk, „Actualité de la Scénographie", nr 27.

Chevalier Jean, Gheerbrant Alain, 1992, Dictionnaire des symboles, Robert Laffont/Jupiter, Paris.

Cixous Hélène, 1987a, „L'Indiade ou l'Inde de leurs rêves” et quelques écrits sur le théâtre, Théâtre du Soleil, Paris.

Cixous Hélène, 1987b, „Si vous le permettez, je vais vous parler d'amour”, w: „L'Indiade ou l'Inde de leurs rêves" et quelques écrits sur le théâtre, Théâtre du Soleil, Paris. (tekst drukowny był także w: „Acteurs” 1987, nr 53).

Cixous Hélène, 1988, Invisible Visible, Visible Invisible, „Double Page”, nr 49.

Cixous Hélène, 1989, Théâtre enfoui, „Europe”, nr 726.

Coen Lorette, 1987, Soleil sur l'Inde, „Mensuel Européen/Emois”, 5 października.

Corvin Michel, 1976, Contribution à l'analyse de l'espace scénique dans le théâtre contemporain, „Travail Théâtral”, nr 22.

Costaz Gilles, 1987, „L'Indiade”: un troupeau d'animaux furieux, „Le Matin”, 28 września.

Domańska Ewa, 1994, Filozoficzne rozdroża historii, w: Między modernizmem a postmodernizmem. Historiografia wobec zmian $w$ filozofii historii, Ewa Domańska, Jerzy Topolski, Wojciech Wrzosek (red.), Wydawnictwo Naukowe UAM, Poznań.

Gandhi Mohandas Karamchand, 1962, India of My Dreams, Navajivan Publishing House, Ahmedabad14.

Gastellier Fabien, 1987, L'India song d'Ariane Mnouchkine, „Le Quotidien de Paris”, nr 2441.

Godard Colette, 1987, Image cruelle d'un rêve de paix, „Le Monde”, 10 października.

Golfier Bernard, 1988, Le tragique de la partition. Entretien avec Hélène Cixous, „Théâtre Public", nr 82-83.

Hassoun Pascale, Maillet Chantal, Rabant Claude, 1988, Entretien avec Hélène Cixous, „Patio”, nr 10.

Kowzan Tadeusz, 1991, Teatr jako uprzestrzennienie literatury, tłum. Halina Kowzan, „Dialog", nr 8.

Le Roux Monique, 1987, Gandhi et l'ourse, „Le Quinzaine Littéraire”, nr 497.

Lefort Rafael, 1995, Mistrzowie Gurdżijewa, przekład zbiorowy, Troubadour Publications, Montreal.

Nehru Jawaharlal, 1957, Rozmowy z Nehru, przeprowadził Tibor Mende, tlum. Zofia Jaremko-Pytowska, Książka i Wiedza, Warszawa.

Neuschäfer Anne, 1975-1999: De la création collective à l'écriture en commun, www. lebacausoleil.com.

Pavis Patrice, 1990, Le théâtre au croisement des cultures, José Corti, Paris.

Picard Anne-Marie, 1989, L'Indiade ou l'Inde de leurs rêves, „Dalhousie French Studies”, nr 15-17.

Quillet Françoise, 1999, L’Orient au Théâtre du Soleil, L'Harmattan, Paris-Montréal.

Rachwał Tadeusz, Sławek Tadeusz, 1992, Maszyna do pisania. O dekonstruktywistyczniej teorii literatury Jacquesa Derridy, Oficyna Literatów „Rój”, Warszawa.

Ratajczakowa Dobrochna, 1999, Wprowadzenie, w: Na schodach Klio. Jedenaście ćwiczeń z myśli o dramacie historycznym, Dobrochna Ratajczakowa, Izolda Kiec (red.), „Poznańskie Studia Polonistyczne. Seria Literacka”, Poznań. 
Renik Krzysztof, 1994, Kathakali. Sztuka indyjskiego teatru, Wydawnictwo Akademickie Dialog, Warszawa.

Servin Micheline, 1988, Le rêve, cet autre visage de la réalité, „Les Temps Modernes”, nr 43 (499).

Temkine Raymonde, 1987, L'epopée indienne, „Acteurs”, nr 53.

Thomasseau Jean-Marie, 1995, Drame et tragédie, Hachette, Paris.

Ubersfeld Anne, 1981, L'école du spectateur, Edition Sociales, Paris.

White Hayden, 2000, Poetyka pisarstwa historycznego, Ewa Domańska, Marek Wilczyński (red.), Universitas, Kraków.

\section{QUASI-BIBLICAL HISTORY}

Summary

L'Indiade, ou l'Inde de leurs rêves is the second drama of Hélène Cixous directed by Ariane Mnouchkine in the Théâtre du Soleil. The history of India - the achievement of independence in 1947 marked by the division of the country - became a metaphor of the separation experienced in the closest relationships between people. The performance rooted in the historical and socio-political realities also exhibited its universal dimension through references on many planes to the Bible, Mahabharata and Greek tragedies. The topic of separation was reinforced in a special manner by its contrast with the quality most characteristic for India, with variety and contrast, present in rhapsodic literate form which refers to Shakespearian chronicles, but also existing at the level of the story, the characters, the construction of the spectacle and theatrical creations. The performance, revealing the riches incorporated into the human being, inspired posing one of the most fundamental questions, what is man?

\section{Key words/słowa kluczowe}

performance / inscenizacja; Shakespearian chronicles / kroniki szekspirowskie; modern tragedy / tragedia współczesna; rhapsodic form / rapsodyczność; Indian mosaic / indyjska mozaika 